\title{
CIVIL LEGISLATION OF UKRAINE AND ITS LIMITS
}

\author{
Shyshka O. R.
}

\section{INTRODUCTION}

According to the Resolution of the Cabinet of Ministers of Ukraine of July 17, 2019 No. 650 it has been set a course for updating the civil legislation of Ukraine. Therefore, today there is a need to revise not only the rules of civil legislation but also existing paradigms and accumulated legal knowledge. One important aspect of such revise is the understanding of civil legislation and its system, including the verification of such legislation on compliance with the principle of supremacy of law, in particular, with such its components as the effectiveness of the aim and means of legal regulation, reasonableness, predictability, determinancy and logicality of its constituent elements, that is, the normative-legal array. The need to update the civil legislation of Ukraine is caused by global trends in mankind development and progress, which ceaselessly affect the social life of man, and with them there are new challenges and demands for legal formalization of relationship, which either do not fit into the concept of regulation of the sphere of civil law, or mechanisms of legal regulation are powerless to ensure the inviolability of the rights and interests of the participants of civil relations. This also applies to the idea of developing common world standards of the legal regulation of civil relations.

Today there are two main approaches to understanding the term 'civil legislation of Ukraine' and its system according to Chapter 1 of the Civil Code of Ukraine in Ukrainian scientific literature. In accordance with the first one $\begin{array}{lll}\text { (N. S. Kuznetsova } & \\ & \text { A. S. Dovhert }\end{array}$, $\quad$ R. A. Maidanyk ${ }^{3}, \quad$ Yu. O. Zaika ${ }^{4}$,

${ }^{1}$ Кузнєцова Н. С. Акти цивільного законодавства. Енциклопедія циивільного права Украӥни. Ін-т держави і права ім. В. М. Корецького НАН України ; відп. ред. Я. М. Шевченко. Київ : Ін Юре, 2009. С. 30; Кузнєцова Н. С., Довгерт А. С. Сучасне цивільне законодавство України: здобутки, проблеми, перспективи. Вісник Південного регіонального иентру Національної академії правових наук Украӥни. 2014. № 1. С. 59-60. URL: http://nbuv.gov.ua/UJRN/vprc_2014_1_7.

${ }^{2}$ Кузнєцова Н. С., Довгерт А. С. Сучасне цивільне законодавство України: здобутки, проблеми, перспективи. Вісник Південного регіонального центру Національної академії правових наук України. 2014. № 1. C. 59-60. URL: http://nbuv.gov.ua/UJRN/vprc_2014_1_7/.

${ }^{3}$ Майданик Р. А. Цивільне право: Загальна частина / Т. І. Вступ у цивільне право. Київ : Алерта, 2012. С. 330, 336-338.

${ }^{4}$ Цивільне право України. Загальна частина / за ред. Бірюкова I. А., Заіки Ю. О. Київ : Алерта, 2014. С. 26. 
R. B. Shyshka ${ }^{5}$, L. V. Krasytska ${ }^{6}$, D. V. Bobrova ${ }^{7}$, O. Ye. Kukharev ${ }^{8}$, V. I. Truba ${ }^{9}$, S. N. Prystupa ${ }^{10}$, etc.) civil legislation is understood as the system of normative legal acts that contain the rules of civil law. The essence of this approach is mainly confined to that 'civil legislation' and 'acts of civil legislation' are identical notions, and its system, as it is noted by L. V. Krasitska, consists of the Constitution of Ukraine, the Civil Code of Ukraine and other codified acts, the Laws of Ukraine; subordinate normative legal acts; international treaties regulating civil relations, the consent to be bound by which was given by the Verkhovna Rada of Ukraine ${ }^{11}$. At the same time, both in science and in practice this approach is considered a dogma that doesn't question. The second approach (Ye. O. Kharytonov) considers the term 'civil legislation of Ukraine' more broadly than the first one, namely, as the whole set of formally fixed rules regulating civil relations ${ }^{12}$. In this case, the system of civil legislation of Ukraine includes: the acts of civil legislation of Ukraine, contracts of the subjects of civil law, customs, international treaties, other forms of civil legislation (legal doctrine, precedents, corporate norms, etc. $)^{13}$. However, as we can see, such a system at the national level does not reflect all the regulators of civil relations which one way or another affect the ordering of civil relations. But, before attempting to improve the system of sources of civil law, it is necessary to figure out the normative-fixed model of system of civil legislation of Ukraine, what this research is devoted to.

\footnotetext{
${ }^{5}$ Цивільне право України : підручник, 2-ге вид., перероб. і доп. У 2 частинах / за заг. ред. проф. Р. Б. Шишки, Ч. 1. Загальна. Київ : Ліра, 2018. С. 50-51.

${ }^{6}$ Сучасні проблеми цивільного права та процесу : навч. посіб. / С. О. Сліпченко, О. В. Синєгубов, В. А. Кройтор та ін.; за ред. Ю. М. Жорнокуя та Л. В. Красицької. Харків : Право, 2017. С. 54-55.

7 Цивільне право України: Підручник: у 2-х книгах. Кн. 1 / за ред. О. В. Дзери, Н. С. Кузнєцової. Київ : Юрінком Інтер, 1999. С. 31.

8 Цивільне право України : навчальний посібник : у 2 ч. Ч. $1 /$ за заг. ред. В. А. Кройтора, О. Є. Кухарєва, М. О. Ткалича. Запоріжжя : Гельветика, 2016. С. 21.

9 Труба В. Цивільне законодавство. Енциклопедія цивільного права Украӥни/ Ін-т держави і права ім. В. М. Корецького НАН України ; відп. ред. Я. М. Шевченко. Київ : Ін Юре, 2009. С. 887.

${ }^{10}$ Цивільне право : підручник : у 2 томах, Т. 1 / за ред. В. І. Борисової, І. В. СпасибоФатєєвої, В. Л. Яроцького. Харків : Право, 2011. С. 20.

${ }^{11}$ Сучасні проблеми цивільного права та процесу : навч. посіб./ С. О. Сліпченко, О. В. Синєгубов, В. А. Кройтор та ін.; за ред. Ю. М. Жорнокуя та Л. В. Красицької. Харків : Право, 2017. С. 55-56.

${ }^{12}$ Харитонов Є. О. Категорії «приватне право», «цивільне право України» та «цивільне законодавство України»: до проблеми співвідношення. Наукові праці Національного університету «Одеська юридична академія» : зб. наук. пр. Одеса : Юрид. л-ра, 2012. Т. 12. C. $166,157-169$.

${ }_{13}$ Цивільне право України : Підручник / Є. О. Харитонов, Н. О. Саніахметова. Київ : Істина, 2003. С. 30.
} 


\section{The Ukrainian model of the system of civil legislation in accordance with Chapter 1 of the Civil Code of Ukraine (realm of due)}

Chapter 1 of the Civil Code of Ukraine should be analyzed to answer the posed question.

The determined issue is primarily attributed to the conception of the Civil Code of Ukraine, which originates from Art. 1. The content of this article provides for the requirements that identify certain relations as civil and what regulates these relations is called civil legislation. In particular, Art. 1 of the Civil Code of Ukraine establishes that the civil legislation regulates personal non-property and property relations (civil relations), based on legal equality, free expression of the will, property independence of their participants.

Within the framework of the above issues, the question arises: what does belong to the civil legislation? To answer this question, the laws of logic and the rules of linguistic (grammatical, literal) interpretation should be applied.

Chapter 1 of the Civil Code of Ukraine is entitled 'Civil Legislation of Ukraine' and consists of 10 articles. By the logic of things, everything related to such a chapter should characterize in one way or another Ukraine's civil legislation and its system. Art. 1 of the Civil Code of Ukraine also draws attention to civil legislation and outlines the relations that fall under its regulation. This leads to the opinion that Chapter 1 of the Civil Code of Ukraine answers several questions. Firstly, what does the civil legislation of Ukraine regulate? Accordingly, civil relations (Part 1 of Art. 1 of the Civil Code of Ukraine), and in cases established by law, also some other relations that are not civil (Part 2 of Art. 1 of the Civil Code of Ukraine). Secondly, what does belong to the civil legislation? Answering this question, but without going into a detailed analysis of this chapter, we can make assumptions that the civil legislation covers the acts of civil legislation (Art. 4 of the Civil Code of Ukraine), contract (Art. 6 of the Civil Code of Ukraine), custom (Art. 7 of the Civil Code of Ukraine), international treaties (Art. 10 of the Civil Code of Ukraine). At least this is indicated by the title and structure of Chapter 1 of the Civil Code of Ukraine.

In such circumstances, we can presume so far that the category 'civil legislation of Ukraine' is broader than such notions as 'acts of civil legislation', 'contract', 'custom', 'international treaties', that is, generic concept in relation to the above stated notions, which should accordingly be considered as specific ones. The aforesaid should also lead to another logical conclusion that the category 'civil legislation of Ukraine' have to be commensurate to the category 'source of civil law', and taking into the account that the system of civil legislation may also cover contract, custom and international treaties, along with the acts of civil legislation then the scope of the concept 'civil legislation of Ukraine' have to be considered as a system of legal forms of external expression (fixation) of civil law norms in the state. 
However, such conclusions contradict the current doctrine of civil law, according to which the content of civil legislation of Ukraine consists of acts of civil legislation of Ukraine, that is, of normative legal acts containing civil law norms ${ }^{14}$.

In order to refute or prove the assumptions made, Chapter 1 of the Civil Code of Ukraine should be analyzed in detail.

Particularly, Art. 4 is entitled 'Acts of Civil Legislation of Ukraine'. It is known that the acts of civil legislation act as sources of civil law, the separate forms of legal regulation, and therefore such acts regarding civil legislation are considered as specific and generic concept. This is confirmed by the following logic way. Thus, by applying the one of the laws of logic, namely the law of the inverse relation between the content and the scope of the concept, it is to be concluded, that the scope of the concept 'acts of civil legislation of Ukraine' falls entirely within the scope of another, wider in scope concept, that is 'civil legislation of Ukraine'. Just as the 'civil legislation of Ukraine' is included into the scope of broader in scope concept 'Ukrainian legislation'. Consequently, the acts of civil legislation of Ukraine have to be a type of civil legislation.

In the context of this article, attention should also be paid to Part 1, which states that the Constitution of Ukraine is a basis of the civil legislation of Ukraine. Although Art. 4 is entitled 'Acts of Civil Legislation of Ukraine', but the lexical and grammatical structure of sentence of Part 1 is more general and applies not only to the acts of civil legislation, but also to other components of civil legislation of Ukraine. Considering this, it is logical to conclude that along with the acts of civil legislation, a separate element of the system of civil legislation of Ukraine is the Constitution of Ukraine. At least, the analyzed article indicates this and emphasizes that the Constitution of Ukraine is at the heart of all civil legislation. An argument may also be that civil legislation is not a type of normative legal act.

Along with the Constitution of Ukraine and the acts of civil legislation of Ukraine, a special place in the system of civil law of Ukraine is occupied by the general principles of civil legislation. Art. 3 of the Civil Code of Ukraine entitled 'General principles of civil legislation' indicates this. Thus, if we again apply to the law of the inverse relation between the content and the scope of the concept, we can conclude that the scope of the concept 'general principles of civil legislation' is included in the scope of another, broader concept that is 'civil legislation'. Accordingly, like the acts of civil legislation,

\footnotetext{
${ }^{14}$ Майданик Р. А. Джерела цивільного права України : поняття, система, види. Правова доктрина Украӥни : у 5 т. Т. 3 : Доктрина приватного права України/ за заг. ред. Н. С. Кузнєцової. Харків : Право, 2013. С. 199-202.
} 
the general principles of civil legislation have to occupy a special place in the system of civil legislation of Ukraine. By the way, if we compare such collocations as 'general principles of civil legislation' and 'acts of civil legislation', which by their name are of the same type, the conclusion have to be drawn that the acts of civil legislation are not the general principles of civil legislation, and vice versa. Therefore, the general principles of civil legislation are not the part of the acts of civil legislation of Ukraine, as it is considered to be.

Let's also try to prove this with another article. Art. 8 of the Civil Code of Ukraine, which contain the rules of application of analogy, should be taken as a basis. Part 2 establishes that the general principles of civil legislation are applicable to the regulation of civil relations where an analogy of statute cannot be used. According to Part 1, the analogy of statute applies, if civil relations are not regulated by the Civil Code of Ukraine, other acts of civil legislation or contract, they are regulated by those legal norms of the Civil Code of Ukraine, other acts of civil legislation that regulate similar in content civil relations.

If we consider the general principles in the context of the acts of civil legislation as part of the legal norms of the Civil Code of Ukraine, then the application of certain general principles should be covered by an analogy of statute. But by such a logic there can be no analogy of law. Therefore, applying the law of contradiction, and assuming that the legislator was not mistaken in Art. 8 of the Civil Code of Ukraine, it have to be logically concluded that the general principles are separate element of the system of civil legislation of Ukraine, namely a separate form (source) of the establishment of civil law rules in the state, and its provisions make up its content.

Another argument in favor of the fact that the general principles of civil legislation are separate sources of civil law, constituent elements of the system of civil legislation, is the derivative nature of some rules of civil law from those that are inherently primary sources. In particular, the derivative nature of certain rules of civil law from others is stipulated in Part 1 of Art. 4 of the Civil Code of Ukraine, which states that the basis of the civil legislation of Ukraine is the Constitution of Ukraine. Undoubtedly, the whole Constitution of Ukraine cannot be the framework of civil legislation, since such the basic law contains rules of both public and private law. The basic 'bricks' in this aspect may be the norms of private law, which acquire a civil law character by virtue of the adoption of the sphere of civil law at the legislative level in the state. Thereby, the civil law rules set out in the Civil Code of Ukraine are derived from the civil law rules contained in the Constitution of Ukraine. And this means that certain norms of the Constitution of Ukraine act as a certain base, the initial 'bricks' for other rules of civil law, which have, accordingly, a derivative character. But thereof this the 
Constitution of Ukraine does not become part of the Civil Code of Ukraine and other laws of Ukraine, which are enacted in accordance with the Constitution of Ukraine and other normative legal acts, because it is a separate source of civil law. As well as the Constitution of Ukraine, the general principles of the civil legislation of Ukraine also serve as the foundation for other normative legal acts of the system of civil legislation, except, sure, international treaties in force, the consent to be bound by which was given by the Verkhovna Rada of Ukraine. Hence, for these reasons the general principles of civil legislation are an important element of the system of sources of civil law of Ukraine.

Such a normative reference, in its classical approach, contradicts the doctrine of civil law, since in the vast majority general principles are not considered at all as an enshrined separate form of establishment of civil law rules in the state. They are regarded as ideas enshrined in law in certain rules of civil law. The position of a separate source of civil law is supported by O. O. Pervomaiskyi ${ }^{15}$ and R. A. Maidanyk ${ }^{16}$. This idea is upheld by N. S. Kuznetsova and A. S. Dovhert, who call them the laws of natural law ${ }^{17}$. In some legal systems, general principles are explicitly defined as sources of civil law. In particular, Art. 2 of the Civil Code of Romania provides that the law, customs and general principles of law are the sources of civil law ${ }^{18}$. A similar approach was applied in Art. 1 of the Civil Code of Spain ${ }^{19}$.

In the context of the system of civil legislation of Ukraine the question about the place of the contract is raised. The answer to this question is in Art. 6 of the Civil Code of Ukraine. This article is entitled 'Acts of Civil Legislation and Contract'. Using a literal interpretation of this sentence we can conclude that one concept is compared with another as categories of the same order. That is, if the acts of civil legislation are the type of civil legislation, then contract have to be correlated with civil legislation like

15 Первомайский О. А. Понятие источника гражданского права в контексте современного правопонимания : гл. 3, разд. 3. Харьковская цивилистическая школа: в духе традиций : монография/ под ред. И. В. Спасибо-Фатеевой. Харьков : Право, 2011. C. $185-186,190$.

${ }^{16}$ Майданик Р. А. Джерела цивільного права України : поняття, система, види. Правова доктрина Украӥни : у 5 т. Т. 3 : Доктрина приватного права України / за заг. ред. Н. С. Кузнєцової. Харків : Право, 2013. С. 221.

${ }^{17}$ Кузнєцова Н. С., Довгерт А. С. Сучасне цивільне законодавство України: здобутки, проблеми, перспективи. Вісник Південного регіонального иентру Національної академї правових наук Украӥни. 2014. № 1. C. 60. URL: http://nbuv.gov.ua/UJRN/vprc_2014_1_7.

18 Codul civil României : Legea din 17 iulie 2009 nr. 287/2009. URL: http://legislatie.just.ro/Public/DetaliiDocument/175630 (дата звернення 05.02.2020)

${ }^{19}$ Código Civil de España. Real Decreto de 24 de julio de 1889 . Modificación publicada el 04/08/2018. URL.: https://boe.es/buscar/act.php?id=BOE-A-1889-4763\&tn=6\&p=20180804 (дата звернення 05.02.2020). 
specific concept with generic one. Accordingly, a civil law contract have to be considered as a type of civil legislation of Ukraine. Let's try to check it in another way. If the contract, in accordance with Art. 6 of the Civil Code of Ukraine, is capable of regulating civil relations and civil relations, in compliance with Part 1 of Art. 1 of the Civil Code of Ukraine, are regulated by civil legislation, it is logical to conclude that the contract have to be a type of civil legislation of Ukraine.

The contract as a type of civil legislation is covered by the content and logic of Part 1 of Art. 1 of the Civil Code of Ukraine, otherwise, if the contract is not a type of civil legislation, it turns out that part 1 of Art. 1 of the Civil Code of Ukraine does not cover all civil relations. And if not, an absurd conclusion can be drawn up that there are other civil relations which, therefore, have to be regulates by another system of sources of law, which the contract itself belongs to. But then such a system cannot comply with the ascending rules, which are set out in Section I 'Basic Provisions' of the Civil Code of Ukraine, except those related to the contract (we are talking about Art. 6 of the Civil Code of Ukraine), since this section directly relates to the system of civil legislation and other important components of this system.

Part 1 of Art. 8 of the Civil Code of Ukraine also points at the contract as the component of civil legislation. In particular, part 1 provides: if civil relations are not regulated by the Civil Code of Ukraine, other acts of civil legislation or by contract, they are regulated by those legal rules of the Civil Code of Ukraine and other acts of civil legislation that regulate similar in substance civil relations (an analogy of statute). Firstly, this article indicates that the contract regulates civil relations, and according to Part 1 of Art. 1 of the Civil Code of Ukraine civil relations are regulated by civil legislation. Hence, the contract have to be a type of civil legislation. Secondly, the term 'contract, as well as 'acts of civil legislation', are combined in a single row as full-fledged magnitudes of the same order in the lexico-grammatical structure of the sentence, where the contract is not an act of civil legislation, and an act of civil legislation is not a contract. Accordingly, the contract is a type of civil legislation.

Custom also belongs to civil legislation. This follows not only from Chapter 1 of the Civil Code of Ukraine, entitled 'Civil Legislation of Ukraine', but also from Part 1 of Art. 1 of the Civil Code of Ukraine. Thus, if civil relations can be regulated by custom (Part 1 of Art. 7 of the Civil Code of Ukraine) and civil relations are regulated by civil legislation (Part 1 of Art. 1 of the Civil Code of Ukraine), then we can draw a consistent conclusion that custom and civil legislation have to be correlated as specific and generic concept.

The civil legislation of Ukraine also includes an international treaty in force, the consent to be bound by which was given by the Verkhovna Rada of Ukraine. The latter directly follows from the content of Part 1 of Art. 10 of the Civil Code of Ukraine. 
The foregoing leads to the conclusion that Chapter 1 of the Civil Code of Ukraine establishes a legal model of a sufficiently broad understanding of the system of civil legislation of Ukraine, where such a concept in its scope is commensurate with the term 'source of civil law'. This system includes: general principles of civil legislation, the Constitution of Ukraine, relevant international treaties, acts of civil legislation, contract and custom. In accordance with the title of the Book One 'General Provisions' of Section I 'Basic Provisions' and Chapter 1 'Civil Legislation of Ukraine' of the Civil Code of Ukraine the above list is exhaustive today.

\section{The examples of systematization of civil legislation in the legal systems of other states}

\subsection{Russian model of civil legislation system}

In contrast to the Ukrainian system of civil law Russian one is modeled a bit differently. The term 'civil legislation' in the Civil Code of the Russian Federation (hereinafter referred to as the Civil Code of RF) is rather narrowly presented.

In particular, Art. 3 of this Code is entitled 'Civil Legislation and Other Acts Containing the Rules of Civil Law'. From the title of the article we can conclude that the civil legislation is not covered by the concept 'other acts containing rules of civil law', as well as other acts containing the rules of civil law are not covered by the concept 'civil legislation'. This title also indicates that civil legislation refers to the broader concept 'acts containing the rules of civil law'. Therefore, not all the acts containing the rules of civil law form the civil legislation, but in their systemic manifestation civil legislation and [other] acts containing the rules of civil law are constituent elements of the system of the sources of civil law. At the same time, the title of such an article does not reveal the main point namely what the civil legislation of the Russian Federation consists of. To answer this question it is necessary to analyze the content of Art. 3 of the Civil Code of RF.

Paragraph 2 provides that civil legislation consists of the Civil Code of RF and other federal laws adopted in accordance with to it which regulate the relations specified in paragraphs. 1 and 2 of Art. 2 of this Code. From the above norm we can draw the conclusion that civil legislation is made up of the certain laws. These laws include the Civil Code of RF itself and other federal laws adopted corresponding to the Code. The term 'federal laws' does not cover the Constitution of the Russian Federation, since the basic law is not adopted in keeping with the Civil Code of RF, and on the contrary, the Civil Code of RF is enacted in compliance with the Constitution of the Russian Federation. The laws containing the rules of civil law but not adopted according to the Civil Code of RF also do not belong to federal laws. 
This conclusion can be drawn based on the subparagraph 2 of the paragraph 2 of Art. 3 of the Civil Code of RF, which provides that the rules of civil law contained in [other laws] have to comply with the Civil Code of RF. In this case, the term 'other laws' means those laws that can not be attributed to civil legislation, but at the same time, they contain the rules of civil law and satisfy the requirements of the Civil Code of RF.

It is important to say that the Constitution of the Russian Federation (the basic law) can not belong to other acts containing the rules of civil law. This is due to the fact that other acts containing the rules of civil law, in accordance with Art. 3 of the Civil Code of RF, have to comply with the Civil Code, and the basic act of the Russian Federation can not meet the last law, as it already have been stated.

We can draw some specified conclusions from the above mentioned. Firstly, the system of civil legislation of the Russian Federation is reduced only to laws (in the narrow sense of the word), and therefore the Russian model in this aspect has a rather narrowed approach to understanding the term 'civil legislation' compared to the Ukrainian model. Secondly, being the fundamental law the Constitution of the Russian Federation however occupies a separate place among the sources of civil law of RF. This can also be explained by the fact that the rules of the Constitution of the Russian Federation are of primary character towards the other rules of civil law, which are contained in the relevant normative legal acts.

\subsection{Moldovan model of civil legislation system}

In the Civil Code of the Republic of Moldova (hereinafter referred to as the Civil Code of RM) Chapter 1, like in the Civil Code of Ukraine and the Civil Code of RF, is entitled 'Civil Legislation'. Meanwhile, the structure of such a Chapter has completely different content regarding the system of civil legislation. Particularly, Art. 3 of the Civil Code of RM, entitled 'Civil Legislation', discloses the meaning of this notion. Civil legislation, as specified in part 1, consists of the Civil Code of RM, other laws, ordinances of the Government and subordinate normative legal acts, which regulate the relations identified in Art. 2 of the Civil Code of RM and which have to conform to the Constitution of the Republic of Moldova.

It is possible to draw certain conclusions from the given norm. Firstly, civil legislation, in its simplified form, consists of laws and other normative legal acts. Secondly, the Constitution of the Republic of Moldova does not belong to the civil legislation, particularly to the laws (within the meaning of the term 'law' used in Art. 3 of the Civil Code of RM), because such a supreme law cannot correspond to itself, and based on the provisions of Art. 3 of the Civil Code of RM the laws have to conform to the Constitution of the 
Republic of Moldova. Accordingly, it have to be undisputed that the Constitution of the Republic of Moldova occupies a special place among the system of sources of civil law of the Republic of Moldova. Thirdly, the term 'civil legislation' enshrined in the Civil Code of RM is not commensurate with the notion 'civil legislation of Ukraine' as well as with the term 'civil legislation of the Russian Federation'. This can be explained by the fact that the concept 'civil legislation of Ukraine' is broader in scope than the term 'civil legislation of the Republic of Moldova', and the latter is wider in scope than the notion 'civil legislation of the Russian Federation'. The abovementioned demonstrates the different approaches to the systematization of sources of civil law in the legal system of Moldova, Ukraine and Russia.

\subsection{Mongolian model of civil legislation system}

The system of civil legislation of Mongolia is presented in Art. 2 of the Civil Law of Mongolia. In particular, part 2.1. of this article provides that civil legislation consists of the Constitution of Mongolia and other legislative acts adopted under the Civil Law of Mongolia ${ }^{20}$. From the above norm we can conclude that the civil legislation of Mongolia is composed of certain legislative acts, that is shown from the lexical and grammatical structure of the sentence. Thus, civil legislation as a generic concept is represented in this norm by two groups - the Constitution of Mongolia and, accordingly, other legislative acts, which were enacted in compliance with the Civil Law of Mongolia. In this case the word 'other' indicates that the Constitution of Mongolia is also a legislative act and an integral part of the system of civil legislation of Mongolia. However, the Civil Law of Mongolia can not be classified under the civil legislation of Mongolia, because the normative legal act doesn't appear to be adopted in accordance with its own requirements.

The above-mentioned shows that the Mongolian model of the civil legislation system, in comparison with the Ukrainian, Russian and Moldovan models, is substantially different. The essential distinction of this model is that the Civil Law of Mongolia is not an integral part of the system of civil legislation, but the Constitution of Mongolia, unlike the Ukrainian, Russian and Moldovan models, belongs to the civil legislation of Mongolia.

\section{CONCLUSIONS}

To sum up, it should be mentioned that the category 'civil legislation' in various legal systems has different scope of such a legal concept: from its understanding as a system of laws (the Russian model), as a system of laws

${ }^{20}$ Иргэний Монгол улсын хууль : Монгол улсын хууль 2002 оны 1 дүгээр сарын 10-ны өдөр. URL: https://www.legalinfo.mn/law/details/299 (дата звернення 05.02.2020). 
and other normative legal acts (the Moldovan model), as a system of legislative acts (the Mongolian model) to a broader understanding as a system of officially recognized forms (sources) of external expression of the content of civil law matter (the Ukrainian model).

Based on the conducted research, the civil legislation of Ukraine includes: general principles of civil legislation, the Constitution of Ukraine, relevant international treaties, acts of civil legislation, contract and custom. Proceeding from Chapter 1 of the Civil Code of Ukraine the above list is exhaustive for today. This legislative approach conceptually differs from modern legal doctrine, which comes down to the fact that civil legislation is mainly considered as a system of normative legal acts that contain the rules of civil law. Consequently, this makes a determined problem, namely the mismatch between the realm of the due and the realm of knowledge of the due, which does not contribute to a unified legal understanding. In consideration of this when working on the recodification of civil legislation of Ukraine, the need for a revision of either the doctrinal approach to the concept and system of 'civil legislation of Ukraine', or the normative enshrined model defining the concept and system of 'civil legislation of Ukraine', appears.

Expressing my own view on this, I believe that the legislator's approach is quite progressive, although unusual (especially taking into account that the concept 'legislation' covers civil law contract, custom and general principles of civil law) and have to be supported, in view of the current course of recodification of civil legislation of Ukraine. An example of a typicality is the ECHR's approach to the term 'law' under which it understands both the rules fixed in written law and the rules that have emerged in case law (see decision if ECHR 'Tolstoy Miloslavsky v. the United Kingdom' of 13 July 1995, Application No. 18139/91, § 37).

Furthermore, in the context of such a legislative approach, there is a need to take into account and enshrine those sources that are not reflected in Chapter 1 of the Civil Code of Ukraine. In particular, this concerns the practice of the ECHR, which, in accordance with Art. 17 of the Law of Ukraine 'On the implementation of judgments and the application of the practice of the European Court of Human Rights', is a source of law and is often used by courts to resolve the issues of civil law nature. At the same time, it is important to identify that the subject of regulation of such a law, in accordance with its preamble, is only public legal relations, and therefore this law can not be attributed to the civil legislation of Ukraine. The same relates to the acts of official interpretation of rules of law (interpretative legal acts), adopted under the procedure prescribed by law by a relevant state body (for example, the Constitutional Court of Ukraine, the Supreme Court, etc.). While not being sources of law, such acts make a significant effect on the legal understanding of the content of a civil law rule or on the cases and 
procedure for applying a civil law rule to a particular case. The demand for definiteness of such acts of official interpretation of the rules of law in the field of civil law stems from, first of all, the necessity of bringing the current legislation into conformity with the requirements of principle of supremacy of law, namely, the requirements of the legal determinancy. Primarily, this relates to the fact that the application of such acts is regulated only by the rules of procedural law, and the latter cannot be applied in the regulation of civil relations. In addition, this necessity arises from the fact that sometimes the legal position of the Supreme Court becomes not law-interpretating, but law-making, in fact acts as a 'source' of the regulation of civil relations, contrary to the Constitution of Ukraine and the Civil Code of Ukraine. Therefore, when defining acts of official interpretation of the rules of law, including those issued by the Supreme Court, the sphere of civil law requires the fixation of certain legal guarantees, which would be aimed at ensuring the stability and immutability of the rules of civil law, among them the inviolability of the rights and interests of participants of civil relations ${ }^{21}$. Legal revision addresses local legal acts of a legal entity as well, in particular, which serve as a source of regulation of intracorporate relations. Although the solution to this question depends on the resolution of another issue, notably, the place of intracorporate relations in the subject of civil law 22 . The identification of the place of sports regulations or other local legal acts with a manifestation of 'soft law' also requires the revision of knowledge.

${ }^{21}$ See, e.g., Шишка О. Р. Висновки верховного суду України як «джерело» цивільного права : деякі вразливості та проблеми неспівпадіння з концептом ЦК України // Проблеми цивільного права та процесу : тези доп. учасників наук.-практ. конф., присвяч. світлій пам'яті О. А. Пушкіна, Харків, 24 трав. 2019 р. / МВС України, Харків. нац. ун-т внутр. справ; Харків. обласний осередок Всеукр. громад, орг. «Асоціація цивілістів України»). Харків: ХНУВС, 2019. С. 217-222; Шишка О. Р. До постановки проблеми про відповідальність держави Україна за неправомірне втручання Верховним Судом у права людини // Модернізація цивільно-правової відповідальності. Матвєєвські цивілістичні читання. Матеріали міжн. наук.-практ. конф. Київ, 18 жовт. 2019 р. / Р. А. Майданик, Цюра та ін.; відп. ред. Р. А. Майданик. Київ, 2019. С. 333-341.

${ }^{22}$ See, e.g., Шишка А. Р. Концепт статьи 1 ГК Украины: методологический путь к познанию и проблемы // Методология исследования проблем цивилистики : сб. ст., посвящ. памяти проф. А. А. Пушкина / под ред. Ю. М. Жорнокуя и С. А. Слипченко. Харьков : Право, 2017. С. 389-414; Шишка О. Р. До обгрунтування необхідності визначення корпоративних відносин в предметі цивільного права : до постановки проблем // Корпоративне право України та європейських країн: питання теорії та практики : збірник наукових праць за матеріалами XV Міжнародної науково-практичної конференції (6-7 жовтня 2017 р., м. Івано-Франківськ). Івано-Франківськ, 2017. С. 264-269; Шишка О.Р. Предмет цивільного права України: чи настав час переосмислення та формування нової парадигми? // Предмет правового регулювання галузей вітчизняного права: матеріали міжнародної науково-практичної конференції, м. Київ, 15-16 березня 2019 року / ред. кол. І. С. Гриценко, Р. С. Мельник та ін. Київ : Гельветика, 2019. С. 40-45. 


\section{SUMMARY}

According to the Resolution of the Cabinet of Ministers of Ukraine of July 17, 2019, No. 650 it has been set a course for updating the civil legislation of Ukraine. Therefore, today there is a need to revise not only the rules of civil legislation but also existing paradigms and accumulated legal knowledge in this area. One important aspect of such revise is the understanding of civil legislation and its system.

It is also concluded that the category 'civil legislation' in various legal systems has different scope of such a legal concept: from its understanding as a system of laws (the Russian model), as a system of laws and other normative legal acts (the Moldovan model), as a system of legislative acts (the Mongolian model) to a broader understanding as a system of officially recognized forms (sources) of external expression of the content of civil law matter (the Ukrainian model).

Based on the conducted research, the author draw a conclusion that the civil legislation of Ukraine includes: general principles of civil legislation, the Constitution of Ukraine, relevant international treaties, acts of civil legislation, contract and custom.

\section{REFERENCES}

1. Кузнєцова Н. С. Акти цивільного законодавства. Енциклопедія цивільного права України. Ін-т держави і права ім. В. М. Корецького НАН України ; відп. ред. Я. М. Шевченко. Київ : Ін Юре, 2009. С. 30.

2. Кузнєцова Н. С., Довгерт А. С. Сучасне цивільне законодавство України: здобутки, проблеми, перспективи. Вісник Південного регіонального иентру Національної академії правових наук України. 2014. № 1. C. 51-67. URL: http://nbuv.gov.ua/UJRN/vprc_2014_1_7.

3. Майданик Р. А. Цивільне право: Загальна частина / Т. І. Вступ у цивільне право. Київ : Алерта, 2012. 472 с.

4. Цивільне право України. Загальна частина / за ред. Бірюкова I. А., Заіки Ю. О. Київ : Алерта, 2014. 510 с.

5. Цивільне право України : підручник, 2-ге вид., перероб. і доп. У 2 частинах / за заг. ред. проф. Р. Б. Шишки, Ч. 1. Загальна. Київ : Ліра, $2018.736 \mathrm{c}$.

6. Сучасні проблеми цивільного права та процесу : навч. посіб./ С. О. Сліпченко, О. В. Синєгубов, В. А. Кройтор та ін.; за ред. Ю. М. Жорнокуя та Л. В. Красицької. Харків : Право, 2017. 808 с.

7. Цивільне право України: Підручник : у 2-х книгах. Кн. 1 / за ред. О. В. Дзери, Н. С. Кузнєцової. Київ : Юрінком Інтер, 1999. 864 с.

8. Цивільне право України : навчальний посібник : у 2 ч. Ч. 1 / за заг. ред. В. А. Кройтора, О. С. Кухарєва, М. О. Ткалича. Запоріжжя : Гельветика, 2016. 352 с. 
9. Труба В. Цивільне законодавство. Енциклопедія циивільного права України / Ін-т держави і права ім. В. М. Корецького НАН України ; відп. ред. Я. М. Шевченко. Київ : Ін Юре, 2009. С. 887.

10. Цивільне право : підручник : у 2 томах, Т. 1 / за ред. В. І. Борисової, І. В. Спасибо-Фатєєвої, В. Л. Яроцького. Харків : Право, 2011. $656 \mathrm{c}$.

11. Харитонов Є. О. Категорії «приватне право», «цивільне право України» та «цивільне законодавство України»: до проблеми співвідношення. Наукові праці Національного університету «Одеська юридична академія» : зб. наук. пр. Одеса : Юрид. л-ра, 2012. Т. 12. C. $157-169$.

12. Цивільне право України : Підручник / Є. О. Харитонов, Н. О. Саніахметова. Київ : Істина, 2003. 776 с.

13. Майданик Р. А. Джерела цивільного права України : поняття, система, види. Правова доктрина Украӥни : у 5 т. Т. 3 : Доктрина приватного права України / за заг. ред. Н. С. Кузнєцової. Харків : Право, 2013. $760 \mathrm{c}$.

14. Первомайский О. А. Понятие источника гражданского права в контексте современного правопонимания : гл. 3, разд. 3. Харьковская иивилистическая школа: в духе традиций : монография/ под ред. И. В. Спасибо-Фатеевой. Харьков : Право, 2011. С. 157-190.

15. Codul civil României : Legea din 17 iulie 2009 nr. 287/2009. URL: http://legislatie.just.ro/Public/DetaliiDocument/175630 (дата звернення 05.02.2020)

16. Código Civil de España. Real Decreto de 24 de julio de 1889. Modificación publicada el 04/08/2018. URL: https://boe.es/buscar/ act.php?id=BOE-A-1889-4763\&tn=6\&p=20180804 (дата звернення 05.02.2020).

17. Иргэний Монгол улсын хууль : Монгол улсын хууль 2002 оны 1 дүгээр сарын 10-ны өдөр. URL: https://www.legalinfo.mn/law/details/299 (дата звернення 05.02.2020).

\section{Information about the author:} Shyshka O. R., $\mathrm{PhD}$, Associate Professor, Associate Professor of the Department of Civil Law Disciplines,

Lev Landau Avenue, 27, Kharkiv, Ukraine ORCID ID: https://orcid.org/0000-0002-1396-0508 